\title{
AN ANALYSIS OF CODE SWITCHING IN STUDENTS' SPEAKING TEST AS ENGLISH FOREIGN LANGUAGE LEARNERS
}

\author{
Khairun Nisa1* ${ }^{*}$, Habi Septiawan, Rafista Deviyanti \\ University of Lampung \\ Khairun.nisa31092@gmail.com
}

\begin{abstract}
This research aims at finding out types of code switching occurred in students' speaking test of EFL learner, the percentage of each type, and finding out the students' reasons in switching their language. Three types of code switching proposed by Poplack (1980); intra-sentential switching, intersentential switching, and tag switching were analyzed in this descriptive qualitative study. There was one class as the sample of this research. After gaining the data, the researcher categorized the data based on three types of code switching mentioned above. The result revealed that all three types of code switching appears in the students' speaking. The first type, intra - sentential switching, it tends to be the main type of switching (69.49\%), followed by intrasentential switching (27.12\%). Different from those two types, tag switching seems to occur the least frequent type of switching that appeared in the comments (3.39\%). Then, the researcher also classified the data into seven reasons in doing code switching according to Hoffman (1991). There are still some other reasons found by the researcher in conducting the research.
\end{abstract}

Keywords: code switching, EFL learners, speaking test

\section{A. INTRODUCTION}

The phenomenon of Code Switching (CS) has attracted a great amount of research as it concerns a fundamental part of our lives, communication and interaction (Chloros, 2009). Code-switching is a phenomenon when there are two or more language exist in a community and it makes speakers frequently switch from one language to another language (Hornberger \& McKay, 2010). As a consequence, the literature on CS is rich, drawing interest from disciplines such as linguistics, sociology and anthropology and creating a wide range of opinions on the question why people choose a certain linguistic 
variety over another one. Study of language is very important because through the language we can introduce the status of who we are. In everyday, we always use the language for communication while in communication people are usually selecting a particular code whenever they choose to speak, and they may also decide to switch one code to create a new code.

People, then, are usually required to select a particular code whenever they choose to speak, and they may also decide to switch from one code to another or to mix codes even within sometimes very short utterances and thereby create a new code Wardhaugh (1997). Gumpersz's (1971) of code switching in the community reveals that the situation is quite complex because of the number of possibilities that are available with the right choice highly dependent on the social context and intent of the speakers.

Myers-Scotton (1993) and Scotton (1983) has tried to account for code switching by proposing that speakers have unmarked and marked choices available to them when they speak. These choice vary by situation. Code switching is that it involves the alternate use of two languages or linguistics varieties within the same utterance or during the same conversation (Hoffman,1993). According to Hymes (1875) code switching has become a common term for alternate use of two or more language, varieties of language or even speech styles. In similar way, Romaine (1994) says that many linguists have stressed the point that switching is a communicative option available to a bilingual member of speech community on much the same basis as switching between styles or dialects is an option for the monolingual speaker.

Meanwhile, Hudson (1980) proposes that great sociolinguistics proposes that language code switching can be done by using two languages once or changing totality from one language to another. They are language switching by using two or more languages at once and language switching by changing completely from one language to another. In this research, the writer tries to classify code switching in students' speaking into three kinds of code switching based on Poplack. The researcher will briefly review the 
relevant distinctions that were made to point out differences between code-switching patterns. Poplack`s distinction among tag switching, inter-sentential switching, and intra-sentential switching (Poplack 1980).

As one would expect, research on English as one part of the language pair is abundant but the same does not happen for the other language examined in this study, Indonesian. The aim of the current study is to classify students' speaking into some types of code switching based on Hoffman in conversation of third level students in English course class, which requires good or fluent command of English. Most students learn English from a very young age (6-8 years old), though some of them never achieve a fluent level. As an outcome of living in a foreign country and participating in an institutional environment, this group of people will come in contact with its language and culture. Thus, this interaction affects their language use. Besides, the result also will show what their motivations are doing this in communication.

After doing this study, the researcher expect that the result can answer these questions: What do types of Code-Switching emerge in the students' speaking?; How is the frequency of each types of Code-Switching in students' speaking?; and What are the students' motivations of using Code-switching in their speaking?

\section{B. METHOD}

This research used descriptive qualitative research. The researcher took a class of third level English course students as the samples which consisted of nine students. The researcher analyzed the data by using several steps. First, the data were transcript and put into a table. The second was grouping the data where the data were classified based on the three types of code-switching from Poplack (1980). Then, the researcher analyzed the data into several kinds of reason from Hoffman (1991). The last, the researcher described other possible reasons by considering the observation done by the researcher. The theories termed to classify the data to answer the first research question used from Poplack (1980). 


\section{Intra-sentential Switching}

This is one of the types in code-switching which involves the switch that occurs at the level of words within sentences. The switching can be in the middle of sentences, clauses, or even words.

\section{Inter-sentential Switching}

This kind of code-switch occurs within a clause boundary. Intra-switching represents switching at the clause, phrase level, or at word level if no morphological adaption occurs and the mentioned above criteria for the distinguishing codeswitches and borrowings are observed. This involves a switch at a clause or sentence level in different languages". The switching either at clauses or between sentences in one language conforms to the rules of the other languages.

\section{Tag Switching}

The last type of code switching that analyzed in the study is tag switching. Regarding this type of switching involves the insertions of tag in one language into one sentence or utterance in another language. These tags can be inserted anywhere, which are in other language.

These Three categories of code switching are used as the basis for analyzing the data. The frequency of each type was then calculated and compared in terms of percentages to answer the second research question. While to answer the last research question, the researcher described all the possible reasons that make the students do code switching focus on theories given by Hoffman (1991) who classified the reasons to do code switching into seven points, they are as follow:

a. Talking about a particular topic

People sometimes prefer to talk about a particular topic in one language rather than in another. Sometimes, a speaker feels free and more comfortable to express their 
emotions, excitements, or even anger in a language that is not their everyday language.

b. Quoting somebody else

Regarding this reason, Hoffman (1991) suggested that "people sometimes like to quote a famous expression or saying of some well-known figures".

c. Being emphatic about something

Usually, when someone who is talking using a language that is not his native tongue suddenly wants to be emphatic about something, as Hoffman (1991) stated "he/she, either intentionally or unintentionally, will switch from his second language to his first language.

d. Interjection (Inserting sentence fillers or sentence connectors)

Regarding the reason, Hoffman (1991) suggested that "language switching and language mixing among bilingual or multilingual people can sometimes mark an interjection or sentence connector. It may happen unintentionally or intentionally.

e. Repetition used for clarification

About this reason, Hoffman (1991) said that "when a bilingual wants to clarify his/her speech so that it will be understood more by the listener, he/she can sometimes use both of the languages that he masters saying the same utterance (the utterance is said repeatedly.

f. Intention of clarifying the speech content for interlocutor

When a bilingual person talks to another bilingual as suggested by Hoffman (1991), it was mentioned that there will be lots of code switching and code mixing that occur. It means making the content of his/her speech runs smoothly and can be understood by the hearer.

\section{g. Expressing group identity}

Code switching and code mixing can also be used to express group identity. The way of communication of academic people in their disciplinary groupings, are obviously different from other groups (Hoffman, 1991). 
Those are some theories termed used in this research to classified the data gathered in the field.

\section{RESULT AND DISCUSSION}

After analyzing the students' speaking, the researcher found that the subject of this research had done code switching in their speaking, which were identified into three types of code switching; intra-sentential switching, inter-sentential switching and tag switching. Here is the percentage of students do code switching in their speaking, which is displayed in the Table 1 below.

Table 1. Total Number and Percentage each Types of Code Switching

\begin{tabular}{ccc}
\hline Kinds of code switching & The frequency & The percentage \\
\hline Intra-sentential switching & 41 & 69.49 \\
Inter-sentential switching & 16 & 27.12 \\
Tag switching & 2 & 3.39 \\
\hline Total & 59 & 100 \\
\hline
\end{tabular}

Table 1 indicates the findings of types of code switching appear in the students' speaking. The findings show that the $64.49 \%$ of the code-switching data goes to intrasentential switching. Here are some examples of intra-sentential switching that the researcher found in the sample:

a) He give aa he gave aa yatim piatu? (3)

b) I think he is still strong aa walaupun? (4)

c) And he choose ..choose mentri? (6)

From the Table 1 it showed that there is $27.12 \%$ goes to inter-sentential switching. The students switched the language at a clause or sentence level in different languages. The switching either at clauses or between sentences in one language conforms to the rules of the other languages. There are the examples that were found by the researcher:

\section{a) Tunggu kak ini susah, cari yang lain (1) \\ b) Kasian sih kak, kak tika aja (2)}




\section{c) kaya gimana? (3)}

The last is tag switching. From the Table 1, tag switching only pops up twice with the percentage $3.39 \%$. There are two tag switching that were found by the researcher:

a) Deri ya? (1)

b) Story telling yah? (2)

Those are the examples of code switching based on each type. This numbers show that intra-sentential switching is the most type of code switching which employed by the students with the percentage $69.49 \%$. This result is contrary difference from the previous research of Yuliana (2015) which stated that intra-sentential mostly used and the followed by inter-sentential.

Answering the third research question, this section discusses reasons for the students to do code switching in their speaking. In this case, the present study uses theories given by Hoffman (1991) that concerned about the reasons for code switching. Based on the analysis of the researcher. There are 7 criteria of reasons students do code switching according to Hoffman. The researcher had classified it into the table below.

Table 2 The Classification of Students' Reasons to Do Code Switching

\begin{tabular}{ll}
\hline \multicolumn{1}{|c}{ The Reasons to Do Code Switching } & \multicolumn{1}{c}{ The Data } \\
\hline Talking about a particular topic & 1) Syahrini become for like manja manja manja \\
Quoting somebody else & (12) \\
& 2) Jambul katulistiwa and what is that (37) \\
Being emphatic about something & 1) Do not come late, bla bla bla, udah (10) \\
Interjection (Inserting sentence fillers & 2) And then... udah (19) \\
or sentence connectors) & 2) Story telling yah? (2) \\
Repetition used for clarification & 1) Ee perempuan girl? (25) \\
& 2) Recently he have one cucu satu cucu (27) \\
& 3) And it is thin tirus (32)
\end{tabular}




5) Apa yah banyak banget Many places (13)
Intention of clarifying the speech
content for interlocutor
2) I think he is still strong aa walaupun? (4)
3) And he choose ..choose mentri? (6)
4) he must to try be sabar (7)
5) Prepare bentar (8)
6) Yes today I am finish the SBMPTN tadi pagi
7) And baru baru ini? (26)
8) If he talk is medok jawa (28)
9) I say tirus because mmm (33)
10) In Indonesia we say carper (35)
11) And then many the other place kuliner Food gitu
(38)
12) Mana sih? (16)
1) Assalamualaikum (3)
2) Walaikumsalam (4)
3) Astaghfirullahalazim (6)

There are some reasons why students employed code switching. Beside those reasons, the researcher found that there are some codes switching which cannot be classified to those reasons such as:

a) But I think Kak aul already told you right? (9)

b) Prepare bentar (8)

c) Langsung yah? (8)

Based on the analysis, the researcher found that those codes switching are not classified in that table. There are some reasons that motivate students do code switching based on the researcher's observation, they are:

1) Students are afraid making mistakes so they prefer to use their first language.

For example:

a) Langsung yah? (8)

b) Danu gak ada, danu sama Manda (10) 
2) Students do not know some words so that they ask the word by using L1. For example:

a) and she ... lebay, apa sih ms? (18)

b) can help membangun apa? Will.. (5)

3) Students get used to use L1 so sometimes they use L1 in expressing their feeling.

For example:

a) When I feel fat and hilaf I do it (30)

b) Kasian sih kak, kak tika aja (2)

4) Students are influenced by their culture so that they mix their L1 in speaking L2.

For example:

a) But I think Kak aul already told you right? (9)

b) Hello Kak Nisa (36)

From the finding, it can be interprated that code switching happened because of several reasons. In the other hand, by doing code switching, the students felt easier to express their idea by using both L1 and L2. The problem then from this finding, it could be found that even though in speaking test, the students tended to use L1 than tried to find the closest meaning word in L2 to deliver their idea.

\section{CONCLUSION AND SUGGESTION}

It comes to the conclusion that English course students did code switching in their speaking. The data presents that all the three types named tag, intra-sentential and intersentential switching, appeared in their speaking. Data suggested that among all the three types of code switching, it appears that intra - sentential switching tends to be the main type of switching, followed by inter-sentential switching. Different from those two types, tag switching seems to occur the least frequent type of switching that appeared in the comments (3.39\%). From these research findings, it could give another sight to the teacher as the evaluation in teaching since the students tended to do code- 
switching than use the other words to replace the difficult words. Probably by treating more negotiation meaning or describing words can help them later to lessen doing code switching in speaking. Besides, for further studies that will discuss code switching. It is suggested that further studies can analyze the functions in each type of code switching. Moreover, since there is still a small number of research on code switching in writing, therefore, it could analyze other written literary works, e.g. novels, poetry or even drama scripts.

\section{REFERENCES}

Chloros, Penelope Gardner. (2009). Code Switching. London: Birkbeck College University of London.

Gumperz, Jhon. J. (1971). Language In Social Groups. Standard: Standford University Press.

Hoffman, Charlotte. (1991). An Introduction to Bilingualism. London and New York. Longman Inc.

Hornberger, N.H., \& McKay, S.L. (2010). Sociolinguistics and Language Education. Great britian: Short Run Press.

Hudson, Richard (1980). Sociolinguistics. Cambridge: Cambridge University Press.

Hymes, D. H. (1974). Foundations in Sociolinguistics: An Ethnographic Approach. Philadelphia: University of Pennsylvania Press.

Myers-Scotton, C. (1993). Social Motivations for Code Switching. Evidence from Africa. Oxford: Clarendon Press.

Poplack, Shana. (1980). Sometimes I'll start a sentence in Spanish y termino en español: toward a typology of code-switching. Linguistics 18: 581-618.

Wardhaugh, Ronald. (1997). A Introduction to Sociolinguistics. New York: Basil Blackwell.

Yuliana, Nana et al. (2005). Code-Mixing \& Code-Switching of Indonesian Celebrities: A Comparative Study. Jurnal Lingua Cultura. Vol 9. No 1. 